\author{
Aleksander Fieduta \\ Wydział Nauk Społecznych i Politycznych \\ Europejski Uniwersytet Humanistyczny w Wilnie \\ e-mail: feodor1964@yandex.ru
}

\title{
Przeklęty i zapomniany? \\ Sceny z życia Józefa Emanuela Przecławskiego. Część druga
}

\section{O tym, jak były redaktor walczył o prawo do pamięci}

Po przejściu na emeryturę Józef Emmanuel Przecławski, ostatecznie przemieniony w tajnego radcę Осипа Антоновича Пржецлавского [Osipa Antonowicza Prżecławskiego] ${ }^{1}$, bezpiecznie osiadł w majątku swojej żony, położonym w guberni twerskiej - między dwoma rosyjskimi stolicami, Petersburgiem i Moskwą. To właśnie tutaj zaczął pracować nad swoimi wspomnieniami, które stały się dla byłego polskiego dziennikarza i rosyjskiego cenzora ostatnim dziełem życia. Historię prac nad nimi i walki z wewnątrzredakcyjną cenzurą zawierają jego listy do wydawcy czasopisma „Русский Архив" [„Rosyjskie Archiwum”] Piotra Barteniewa, przechowywane w Rosyjskim Państwowym Archiwum Literatury i Sztuki [РГА ИИ, zbiór nr 46].

1 W oryginalnej, rosyjskojęzycznej wersji artykułu występuje kilka odmian pisowni nazwiska Przecławskiego: Пшецлавский, Пржецлавский, Пршецлавский. Zdaniem Autora studium nie wynikają one tylko z niekonsekwentnej ortografii polskich nazwisk w dziewiętnastowiecznej Rosji, ale sygnalizują również dynamikę tożsamości Przecławskiego, o czym Fieduta pisze w innym miejscu (zob. A. Fieduta, Język jako narodowość: Józef Emanuel Przecławski [Пшецлавский] albo Osip Antonowicz Prżecławskij [Пржецлавский]? w: Georomantyzm - literatura - miejsce środowisko, red. E. Dąbrowicz, M. Lul, K. Sawicka-Mierzyńska, D. Zawadzka, Białystok 2015). Podobnie jak w pierwszej części publikowanego artykułu, redakcja zdecydowała się jednak - dla klarowności wywodu - pozostać przy jednolitej i tradycyjnej pisowni nazwiska Przecławskiego w tłumaczeniu partii odautorskich, zachowując oboczności w cytatach ze źródeł i przypisach [przyp. red.]. 
Korespondencja miała miejsce w latach $1872-1873$ w związku z publikacją na łamach „Rosyjskiego Archiwum” pierwszych rozdziałów Kalejdoskopu wspomnień Osipa Antonowicza. Były one drukowane pod pseudonimem „Ципринус" [„,Cyprynus”]: na herbie rodowym Przecławskich znajdował się karp, którego łacińska nazwa posłużyła za podstawę pseudonimu.

Wszystko wskazuje na to, że poparł Przecławskiego jeden z synów znanego rosyjskiego poety, bohatera-partyzanta wojny 1812 roku D. W. Dawydowa², Wasyl Denisowicz Dawydow (1820 a. 1822-1882), który wspomina o tym w liście do Barteniewa z 10 października 1873 r.

Dwa lata temu los zetknął mnie z Os[ipem] Ant[onowiczem] Prżecławskim, w związku z jego pracami literackimi, i dał mi sposobność udzielenia mu pomocy w zamieszczeniu ich na stronach "Ros.[yjskiego] Archiwum". To nakłada na mnie pewnego rodzaju obowiązek, zgodnie z jego życzeniem, przyjęcia roli mediatora $\mathrm{w}$ nieporozumieniach wynikłych między nim a Panem ${ }^{3}$.

Do „nieporozumień” wrócimy nieco później, ponieważ były one następstwem zarówno wysokiej pozycji pamiętnikarza oraz wydawcy, jak i wmieszania się sił zewnętrznych, dostatecznie wpływowych, by dostarczyć Przecławskiemu nieprzewidzianych przeżyć. Dodajmy tylko, że Dawydow był właścicielem majątku w torżockim rejonie twerskiej guberni, więc najprawdopodobniej stąd znał Przecławskiego i postanowił - po sąsiedzku - zrobić przysługę staremu człowiekowi, tym bardziej że akurat $\mathrm{w}$ tamtym okresie publikował na łamach czasopism historycznych materiały związane z życiem swojego ojca.

Pierwsza publikacja Przecławskiego w "Rosyjskim Archiwum” to Jozafat Ohryzko $i$ jego polska gazeta "Słowo"4. Była to polemika z pisarzem i urzędnikiem Mikołajem Wasiljewiczem Bergiem, sugerującym w swoich Uwagach o ostatnim polskim powstaniu, opublikowanych w czasopiśmie Barteniewa w 1870 r., że jakiś wysoko postawiony Polak wspierał Ohryzkę, który tylko dzięki temu uzyskał możliwość prowadzenia gazety, aktywnie przygotowującej (w mniemaniu Berga) powstanie 1863-1864 r. Przecławski słusznie dostrzegł w tych aluzjach atak na siebie i wolał rozpocząć, zamiast kuluarowej, obronę publiczną. Siedemdziesięciotrzyletni starzec wykazał się przy tym dobrą pamięcią i ostrym piórem, co spodobało się redaktorowi: Barteniew zaproponował Przecławskiemu publikację na łamach czasopisma jego wspomnień.

2 Denis Wasiljewicz Dawydow (1784-1839).

3 РГААИ, zb. nr 46, nr inw. 1, jedn. arch. 565, a. 235

4 „Русский Архив” [„Rosyjskie Archiwum” - dalej jako RA] 1872, t. 5, kolumna 1031-53. 
Wszystko wskazuje na to, że pierwszy etap epistolarnego dialogu redaktora z przyszłym autorem „Rosyjskiego Archiwum” niezaprzeczalnie wywarł na tym ostatnim pozytywne wrażenie. W każdym razie Osip Antonowicz pisze z nieukrywaną przyjemnością (list z 14 maja 1872 r.):

Wiele okoliczności złożyło się na to, że tak poniewczasie odpowiadam na Wasz uprzejmy i szczery list. Ale za 5 lub 7 dni mam nadzieję przyjechać do Moskwy i osobiście złożyć Wam wyrazy szacunku i porozmawiać o współpracy, tak dla mnie ważnej, do której pozwalacie sobie mnie zapraszać. Serdecznie dziękuję za zamieszczenie $\mathrm{w}$ „Archiwum” mojego artykułu i przesłanie honorarium ${ }^{5}$.

Jednak później ton tych listów się zmienia. Pomimo faktu, że Przecławski z wdzięcznością przyjmuje solidność Barteniewa w rozliczeniach finansowych ${ }^{6}$, jest poważnie zmartwiony manierą komentowania przez Barteniewa tekstów, które mu się nie podobają. Na przykład fragment eseju Przecławskiego: „Sękowski, rozczarowany, rozzłoszczony ciągłymi niepowodzeniami, doświadczający na sobie wergiliańskiego "sic vos non vobis»" porzucił wreszcie swoje ambitne przedsięwzięcia i całkowicie zagłębił się w literaturze rosyjskiej. Bardzo dobrze uczynił: czas pokazał, że było to jego powołanie" ${ }^{8}$, Barteniew opatrzył następującym komentarzem:

Czytelnicy nasi odczuwają tę uwagę jako obraźliwą i przypominają sobie artykuł ks. W. F. Odojewskiego o znaczeniu Sękowskiego i Bułharyna w rosyjskiej prasie $^{9}$. Z biegiem czasu historia postawi zarzuty przedstawicielom naszej ówczesnej literatury za to, że dopuścili różnych łotrów do zajmowania się losami rosyjskiego słowa drukowanego, i z wdzięcznością wspomni o przeciwdziałaniach, które w pewnym stopniu podejmował baron Delwig w swojej „Gazecie Literackiej”, a później Puszkin w „Aktualnościach”; ale pierwszego zniszczył hrabia Benckerdorff, a drugiego - kula łotra-Francuza. P. B. ${ }^{10}$

Oczywiście Przecławski, mimo skrajnie negatywnego nastawienia do Sękowskiego, natychmiast rusza do walki:

\footnotetext{
5 РГААИ, zb. nr 46, nr inw. 1, jedn. arch. 564, a. 219.

6 Na przykład: „Miałem zaszczyt otrzymać Wasz list z 12 września z załączeniem 120 rubli honorarium za mój artykuł o Nowosilcowie; jestem Wam bardzo wdzięczny za terminowość". O. A. Prżecławski, List do P. I. Barteniewa z 18 września 1872 r., РГА ИИ, zb. nr 46, nr inw. 1, jedn. arch. 564, a. 409.

7 Sic vos non vobis (łac.) - tak więc pracujecie nie dla siebie; kto inny zdobywa owoce waszej pracy [przyp. tłum.].

8 [О. А. Пржецлавский], Калейдоскоп воспоминаний. II. Адам Миикевии, RA 1872, nr 10, kol. 1933.

${ }^{9}$ RA 1864, nr 2, str. 1015.

10 [О. А. Пржецлавский], Калейдоскоп воспоминаний. II. Адам Миикевии, dz. суt.
} 
Nie będę przed Panem ukrywał, szanowny Piotrze Iwanowiczu, że zarówno zdziwił, jak i zmartwił mnie Pański komentarz w 1933 kolumnie 10 numeru, zaczynający się od słów „Czytelnicy nasi odczuwają jako obraźliwą (!) tę uwagę" itd. Proszę mi powiedzieć, z łaski swojej, kogo obraziłem, mówiąc, że „Biblioteka do czytania” Sękowskiego odniosła wielki sukces? Przecież to, po pierwsze, fakt, że tym wydaniem dorobił się przyzwoitego majątku, a po drugie, kto i jak może mi przypisywać intencje, których nie miałem? Czy nie jest trochę nadużywane prawo wydawcy do robienia uwag o publikowanych artykułach? Z pewnością powinienem odpowiedzieć, po to by oczyścić się przed czytelnikami, do których Pan się zwraca, i zdecydowanie poproszę również Pana o publikację mojej odpowiedzi. [...] W celu uniknięcia w przyszłości takich konfliktów, które mogą nas sprowadzić na manowce, prosiłbym Pana o rzecz następującą: za każdym razem, kiedy będzie miał Pan chęć czynić uwagi do moich artykułów, proszę nie omieszkać poinformować mnie o tym przed publikacją w numerze; będzie na to dość czasu, sądząc po terminach ukazywania się numerów „Archiwum”. Może się zdarzyć, że po przedstawieniu moich argumentów, które będę przedstawiał niezwłocznie, Pan od niektórych uwag odstąpi, a w innych poczyni zmiany. Sam Pan pisał mi o tych odpowiedziach, które Panu posłałem osobiście przez mojego syna, co pokazuje, że były rzeczowe. Proponowane przeze mnie rozwiązanie zapobiegłoby takiej niepotrzebnej i jednostronnej polemice $^{11}$.

Istnieją powody do takiej reakcji Przecławskiego, ma on też prawo zaskarżyć komentarz redaktora: ostatecznie nie musi ponosić odpowiedzialności w oczach czytających go Rosjan za złą reputację rodaków - w tym przypadku O. I. Sękowskiego ${ }^{12}$. Przecławski nie pojmuje, dlaczego tak zmienił się przyjazny początkowo ton Piotra Iwanowicza Barteniewa, i z całym swoim polemicznym temperamentem atakuje go, licząc na zrozumienie:

Notuję znane mi fakty i zdarzenia, ale jednocześnie również przemyślenia, i nie mogę zrezygnować z myślenia, osądzania - słusznego bądź nie, choć ostatniego nie zakładam, dopóki to nie zostanie wykazane (wtedy staram się zmądrzeć). Tymczasem widzę, że Pan inaczej pojmuje wymogi, które stawia piszącym do Pańskiego wydawnictwa; nie akceptuje Pan mojego stylu, raz za razem znajdując rzeczy nieodpowiadające Pańskiemu programowi. Nie mogę się przyzwyczaić do takich ograniczeń, ale i nie mogę należycie sobie wyjaśnić, na czym

11 O. A. Prżecławski, List do Р. I. Barteniewa z 21 października 1872 r., РГА ИИ, zb. nr 46, nr inw. 1, jedn. arch. 572, aa. 488-489. [podkr. autora listu]

12 Dodajmy: a następnie Bułharyna. Pamiętnikarski szkic Przecławskiego o Bułharynie, opublikowany w "Rosyjskim Zbiorze”, zostanie opatrzony przez jego redaktora, W. F. Pucykowicza, nie mniej obraźliwym i niesprawiedliwym komentarzem. Zob. o tym zwłaszcza: Feduta A. I. Слово "белорус" в воспоминаниях Осипа Пржеилавского, w: Поэтика и лингвистика. Материаль науиной конферениии, посвященной 100-летию со дня рождения Р. Р. Гельгардта. 16-19 октября 2006 г., Twer 2006, s. 42-44. 
polegają owe ramy, w które pragnie Pan zamknąć piszącego do „R[osyjskiego] Archiwum".

Zgodzi się Pan, szanowny Piotrze Iwanowiczu, że myśl o tym, co może się Panu nie spodobać (z tego, co podoba się innym i za co mi dziękują), zawsze obecna w mojej pracy, nie może jej nie paraliżować i zatrzymywać za każdym razem, kiedy chcę pokazać to, co uważam za istotne i potrzebne. Wiele pisałem do publicznej wiadomości, wydawałem przez 29 lat pismo, i nigdy nie napisałem niczego niestosownego, niczego takiego, czego nie mógłbym obronić przed osądem zdrowej krytyki. Trudne to, niemal niemożliwe dla mnie teraz, na stare lata, od nowa przywyczajać się do pisania zgodnego z taką metodą, której nie mogę zrozumieć. Oto moje położenie w stosunku do Pana, zarysowane z całą szczerością. Cóż mam czynić? ${ }^{13}$

Przecławski nawet nie podejrzewa, jak silnym naciskom jest w tym momencie poddawany Barteniew - mają one na celu przerwanie publikacji wspomnień „Cyprynusa”. Przedstawimy tylko jeden konkretny przykład.

Bratanek Barteniewa, znany później historyk literatury (w szczególności wydawca fragmentów archiwum wielkiego rosyjskiego historyka i pisarza Michaiła Pogodina) N. P. Barsukow, pisze do stryja:

Przede wszystkim uważam za swój obowiązek powiadomić Was o rzeczy następującej: kilka dni temu otrzymałem z Baden-Baden (Langestrasse, 8) list od ks. P. A. Wiaziemskiego, w którym, jak się spodziewałem, wyraża swoje oburzenie - z powodu wpuszczenia na łamy „Rosyjskiego Archiwum”, tej świętej arki naszej przeszłości, „kłamcy Burnaszewa”, który wsławił się swoimi fałszywymi i służalczymi plotkami. [...] Swoje oburzenie wyraża również pułkownik Kropotow, wiele i długo studiujący i nauczający o „murawjewszczyźnie”, za takie samo dopuszczenie do łamów Prżeławskiego (sic!), u którego, zdaniem rzeczonego pułkownika, co słowo, to kłamstwo ${ }^{14}$.

"Rzeczony pułkownik" D. A. Kropotow to znany autor apologetycznej biografii hrabiego M. N. Murawjewa-Wileńskiego [„Wieszatiela" - przyp. tłum.]. Oczywiste jest, że publikacja wspomnień Polaka, bezpośrednio dotyczących czasów opisywanych w pracy Kropotowa (wydał tylko pierwszą część, w której Murawjew występuje w randze gubernatora grodzieńskiego ${ }^{15}$ ), została potraktowana przez pułkownika jako swego rodzaju wyzwanie.

13 O. A. Prżecławski, List do P. I. Barteniewa z 25 stycznia 1873 r., РГА ИИ, zb. nr 46, nr inw. 1, jedn. arch. 565 (cz. I), a. 82 (rew.) - 83.

14 N. Р. Barsukow, List do Р. І. Barteniewa z 18 września 1872 r., РГААИ, zb. nr 46, nr inw. 1, jedn. arch. 564, aa. 407-407 (rew.).

15 Zоb.: Жизнь графа М. Н. Муравьева, в связи с собьтиями его времени и до назначения его губернатором в Гродно. Биографический очерк, составленный $А$. А. Кропотовым, Sankt Petersburg 1874. 
Ale pułkownika Kropotowa i jego oburzenie Barteniew może jeszcze jakoś znieść: w końcu jest wielu pułkowników, zajmujących się pracami historycznymi. Sprawa z księciem Wiaziemskim jest o wiele bardziej złożona. Wiaziemski - były przyjaciel ministra edukacji, senator, człowiek z rozległymi koneksjami i wpływowymi krewnymi - sprawował stały patronat nad czasopismem Barteniewa. To on zwrócił uwagę cara Aleksandra II na „Rosyjskie Archiwum". Skonfliktować się z Wiaziemskim to nastawić wrogo do siebie wielu wysoko postawionych czytelników. I chociaż w przytoczonym wyżej liście Barsukow pisze o gniewie Wiaziemskiego tylko z powodu drugiego z publikowanych przez Barteniewa pamiętnikarzy - Burnaszewa, później staje się jasne: dla Wiaziemskiego Przecławski i Burnaszew to z pewnością osobistości tego samego pokroju, więc publikacja ich tekstów powinna zostać przerwana. Barsukow czuje się w obowiązku ponownie poinformować o tym stryja:

Na miłość boską, najdroższy stryju, musicie jakoś rozwiązać sprawę z Burnaszewem i Cyprynusem. Ks. Wiaziemski jest oburzony na Was za kierunek, który obrało ostatnimi czasy „R[osyjskie] Archiwum”, przez wpuszczenie na łamy tychże osobników. Oburzenie to podzielają także inni szanowani ludzie (w tej liczbie Afan[sij] Fiod[orowicz] ${ }^{16}$ ). A za Nowosilcowa Ks. Wiaz[iemski] rozzłościł się na Was nie na żarty, na szczęście Wasz ostatni list wzruszył go i zażegnał gniew. Te słowa znalazły się w postscriptum; ale w liście cały 9 numer ${ }^{17}$ Książę nazwał „latryną, w której wypróżniają się Cyprynus i Burnaszew”; a pierwszego nazyw[a] „polskim Burnaszewem”. W imieniu Księcia załączam Wam jego przypowieści i inne wiersze ${ }^{18}$.

Oczywiste jest, że tak dosadne oceny Wiaziemski z pewnością wygłasza z założeniem, wyrażonym niemal bezpośrednio, że będą przez bratanka przekazane Barteniewowi. Wiaziemski postawił sobie za cel przerwanie publikacji w "tej świętej arce naszej przeszłości” - „Rosyjskim Archiwum” niewygodnych dla siebie autorów.

Dlatego też aby wyrazić swoje skrajne niezadowolenie z polityki redakcyjnej Barteniewa, Wiaziemski zleca Barsukowowi przesłanie stryjowi swoich epigramatów o personach najbardziej go drażniących w ówczesnym dziennikarstwie historycznym. W ogniu krytyki znaleźli się A. N. Pypin, N. I. Kostomarow, W. P. Burnaszew i O. A. Przecławski. Właśnie Przecławski wydaje się

\footnotetext{
16 To jest akademik A. F. Byczkow, dyrektor Carskiej Biblioteki Publicznej.

17 "Za wyjątkiem notatek Weberna" - uwaga Barsukowa.

18 N. Р. Barsukow, List do Р. І. Barteniewa z 10 października 1872 r., РГААИ, zb. nr 46, nr inw. 1, jedn. arch. 564, a. 429 [podkr. autora listu].
} 
być bohaterem poniższego epigramatu lub, jak określa to Barsukow, „przypowieści":

Заштатный уж давно какой-то сивый мерин,

В журнальной упряжи опять являться стал:

Но вскоре все нашли, что он в езде так скверен,

Что на солому вновь в конюшню он попал.

Он ржанием своим Бартенева пленяет:

$\triangle$ ай прокачусь на нем, Бартенев порешил,

В архивный свой рыдван он клячу запрягает

И думает, что в ход он рысака пустил ${ }^{19}$.

Przecławski jest najprawdopodobniej bohaterem tej niezbyt uprzejmej przypowieści-epigramatu właśnie z powodu swojego wieku: jest znacznie starszy od Burnaszewa. Ale w tym przypadku interesuje nas coś innego: dlaczego Wiaziemski przesyła Barteniewowi - i to jeszcze za pośrednictwem jego bratanka! - tekst, który godzi w dumę wydawcy „Rosyjskiego Archiwum”? Odpowiedź nasuwa się sama: z pewnością dlatego, że jego cel to zdecydowany atak. Wiedząc, że Barteniew nie będzie w stanie bronić się przed epigramatem, nie decydując się na jawny konflikt $\mathrm{z}$ jego autorem, książę zwyczajnie szantażuje przyjaciela.

Z listów Przecławskiego wynika, że Barteniew wciąż próbował łagodzić skutki publikacji wspomnień „Cyprynusa”. Świadczy o tym szczególnie następujący ustęp z listu Przecławskiego: „W pełni zgadzam się z Pana sugestią, żeby nie umieszczać w artykule o Nowosilcowie pełnego nazwiska byłej hrabiny Szuwałowej, a tylko inicjał, mimo że w tym, co się o niej mówi, nie ma nic obraźliwego" ${ }^{20}$. Chodzi o byłą faworytę Nowosilcowa Teklę Zubow (z domu Walentynowicz, secundo voto Szuwałową), której plotka przypisywała nader swobodne zachowanie po śmierci pierwszego męża, księcia Platona A. Zubowa ${ }^{21}$. Oznacza to, że Barteniew dostrzegł groźbę skandalu w publikowanym tekście i doradził pamiętnikarzowi korektę.

19 Nieważny już dawno jakiś siwy wałach, / W pismackiej uprzęży znów się nam objawił: / Lecz szybko odkryto, że w jeździe jest kiepski, / Więc z powrotem na słomę do stajni trafił. / Rżeniem swym jednak urzekł Barteniewa: / Niech się przejadę nim, Barteniew rzekł, / Do archirydwanu zaprzęga więc klacz, / A myśli, że puszcza kłusaka. N. P. Barsukow, List do P. I. Barteniewa z 10 października 1872 r., РГА ИИ, zb. nr 46, nr inw. 1, jedn. arch. 564, aa. 429-429 rew.

20 О. A. Prżecławski, List do Р. I. Barteniewa z 8 lipca 1872 r., РГААИ, zb. nr 46, nr inw. 1, jedn. arch. 564, a. 333.

21 Profesor Uniwersytetu Wileńskiego I. N. Łobojko tak objaśnia sytuację: „Dwa lata przed rozpoczęciem przez niego [Nowosilcowa - przyp. tłum.] śledztwa księżna Zubow, zostawszy wdową po księciu Platonie Zubow, władającym w Kurlandii i guberni wileńskiej ogromnymi majątkami ziemskimi, założyła proces Żerebcowym, jego najbliższym krewnym. Księżna Zu- 
Jednakowoż sprawa nie szła o tego typu łagodzenie efektów publikacji, wszystko wskazuje na to, że zamiary redaktorskie Barteniewa miały na celu zdystansowanie się od pamiętnikarza, pokazanie swego stanowiska jako odmiennego. To ewidentnie wywołuje wewnętrzny protest Przecławskiego:

Nie mogę się także w żaden sposób zgodzić z Pana przekonaniem, że odpowiedzi na Pańskie uwagi nie są zgodne z programem Pańskiego pisma. Jeśli zgodne jest jedno, to nieuchronnie zgodne jest też drugie. W przeciwnym wypadku byłby to jakiś nowy, dotychczas nieznany w literaturze porządek, niezwykle podobny do despotyzmu, żeby nie powiedzieć tyranii. Pana współpracownicy stanowiliby jakieś milczące, nieme stado, które Pan może karać ile wlezie, a oni powinni to wszystko znosić!

I do czego to wszystko prowadzi: tacy współpracownicy, nie znajdując u Pana miejsca dla swoich racji, zaczną uciekać do innych wydawnictw, a wtedy wyjdzie na jaw niebywały skandal walki współpracowników z wydawcą. Nie znajdując miejsca na odpowiedź na Pańskie uwagi do artykułu o Katechizmie, powinienem był wydrukować go w „Wiadomościach S.P.rskich" 22 (nr 249). Pretekstem do tego stały się wybryki w "Głosie", i ja, na ile tylko mogłem, oszczędzałem Pana w swojej odpowiedzi. Ale następnym razem, jeżeli Szanowny Pan nie pozwoli mi na odpowiedź w Pana piśmie, będę zmuszony po prostu wyrazić swoje

bow związała się z Nowosilcowem, szukając jego poparcia dla zgodnego z własną wolą podziału spadku. Za namową swojej matki, zubożałej wileńskiej ziemianki Walentynowiczowej, tak flirtowała z Nowosilcowem, że ten miał nadzieję się z nią ożenić i nie skrywał tego pragnienia. Matka i córka uchwyciły się tej myśli i utwierdzały go w tym mniemaniu. Nowosilcow miał wówczas 70 lat, ale był jeszcze w pełni sił. [...] Nadzieja na poślubienie księżnej Zubow i wzbogacenie się na niej wydawała się Nowosilcowowi na tyle prawdopodobna, że z całym

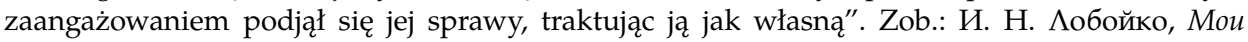
воспоминания, w: Вильна 1823-1824: Перекрестки памяти, Mińsk 2008, s. 163. Wypada jednak zauważyć, że wspomnienia Przecławskiego (przynajmniej w ich opublikowanej wersji) nie zawierają niczego obraźliwego dla eks-księżnej - już komiczniej wygląda nieszczęsny zalotnik: „Ta jego miłosna pasja, spóźniony kwiat głębokiej jesieni życia, była dla mieszkańców Wilna niewyczerpanym źródłem żartów. Żeby uwieść młodą wdowę i zdobyć jej serce, Nowosilcow, zapomniawszy o swoich latach i pozycji, dopuszczał się niewiarygodnych ekscesów i tracił na nie duże pieniądze. Dziennik jego zalotów do księżnej zająłby niemało stron. Codziennie było nowe święto, niespodzianki, pikniki, kawalkady, obiady, bale itd. Nowosilcow występował na pierwszym planie rozrywek gimnastycznych. Stał się i dziarskim jeźdźcem, i desperackim tancerzem. Wyobraźcie sobie Bachusa z siwymi włosami, jak się trzęsie na koniu albo krąży w tańcu. Na cześć księżnej przywrócił nawet dawno zapomniany menuet i wyobrażał sobie, że tańczy go wspaniale. Widząc te ćwiczenia, nie wytrzymałby i sam Heraklit; nic dziwnego, że całe Wilno bez ustanku chichotało i że echo tego chichotu było słychać w Petersburgu i Warszawie.

Zachowanie księżnej w tym przypadku nie mogło być bardziej subtelne i dyplomatyczne. Widocznie bawiło ją to wszystko; ale wątpliwe, żeby dawała siwemu lowelasowi jakieś nadzieje". Cyt. za: О. А. Пржецлавский, Калейдоскоп воспоминаний, w: Поляки в Петербурге в первой половине XIX века, Moskwa 2010, s. 110.

22 "Санкт-Петербургские Ведомости". 
oburzenie na Pana przed czytelnikami i gorzko się poskarżyć. Z konieczności powinienem był zgodzić się na umieszczenie moich odpowiedzi w "Rozmowie", chociaż, powtórzę, moim zdaniem to stanowiłoby w dziennikarstwie przykład niegodny naśladowania ${ }^{23}$.

Przecławski grozi zwróceniem się do czytelników czasopisma i wyprowadzeniem konfliktu poza redakcję. Barteniew drukuje wiele odpowiedzi i zastrzeżeń w stosunku do "Cyprynusa" - m.in. P. W. Kukolnika, N. W. Berga, a także esej P. A. Wiaziemskiego Mickiewicz o Puszkinie, wyraźnie napisany w celu zdezawuowania konkretnych fragmentów wspomnień Przecławskiego. Miłość własna starego człowieka została zraniona. Zwraca się on zatem do wydawcy "Rosyjskiego Archiwum":

Pozwoli Pan, że napiszę o zarzutach, na które narażone są moje artykuły mógłbym przedstawić wiele listów z Petersburga i poprzeć je licznymi ustnymi opiniami, do tego przychylnymi, tak że nie wypada mi powtarzać ich Panu jako wydawcy „Rosyjskiego Archiwum” 24.

Z pewnością istniały podstawy do takich twierdzeń: choćby w archiwum samego Barteniewa udało się odnaleźć list, którego autor, w przeszłości również wysoki urzędnik stołeczny M. Topilski, pisze: „Przy okazji proszę nie omieszkać, jeśli tylko można, powiedzieć mi, dla mojej własnej wiedzy, kim jest Cyprynus, którego artykuły są bardzo interesujące" ${ }^{25}$. Jednak nie jest to zbyt mocny argument: większość opinii o tekstach Przecławskiego, zachowanych w archiwum Barteniewa, ma zdecydowanie negatywny charakter.

Przecławski siegga po niedozwolone chwyty, zaczyna odwoływać się do swojej starości i słabego zdrowia:

Zachorowałem na oczy i nie mogłem kontynuować pracy, jeszcze teraz doktor, pod rygorem najsmutniejszej perspektywy dla moich starych oczu, nie pozwala pracować inaczej jak z długimi przerwami. To najważniejsza rzecz; dlatego muszę szczerze wyznać, że powstałe ostatnimi czasy napięte stosunki między nami nie mogą służyć jako zachęta do bardzo ciężkiej pracy ${ }^{26}$.

23 O. A. Prżecławski, List do P. I. Barteniewa z 28 października 1872 r., РГААИ, zb. nr 46, nr inw. 1, jedn. arch. 564, a. 519 rew. -520 rew.

24 О. A. Prżecławski, List do Р. I. Barteniewa z 4 stycznia 1873 r., РГААИ, zb. nr 46, nr inw. 1, jedn. arch. 565, a. 25.

25 M. Topilski, List do Р. I. Barteniewa z 14 grudnia 1872 r., РГА ИИ, zb. nr 46, nr inw. 1, jedn. arch. 564, a. 525 rew. [podkr. autora listu]

26 О. A. Prżecławski, List do Р. I. Barteniewa z 25 stycznia 1873 r., РГААИ, zb. nr 46, nr inw. 1, jedn. arch. 565 (cz. I), a. 82. 
Jak widać, napięte stosunki z wydawcą są argumentem równie ważnym co choroba. Przecławski próbuje zainteresować Barteniewa wagą poruszanych zagadnień:

Przy pierwszej fizycznej możliwości skończę i poślę Panu rozpoczęty przeze mnie rozdział, zatytułowany Litwa w latach $1810-1830^{27}$ ze Wsteppem, w którym przedstawiam swoje przemyślenia o warunkach, niezbędnych dla Rosjan poznających Polskę i Polaków, by mieli solidny tego osąd, oraz ogólnie o stosunkach między narodami, które wcześniej czy później powinny przejść z aktualnej nienormalnej pozycji do normalnej. [...] Publikacje rosyjskiej prasy, które przyczynią się do przyspieszenia momentu pożądanego zbliżenia dwóch bratnich narodów, zasłużą sobie zarówno u współczesnych, jak i potomnych, okażą się prawdziwie patriotycznemi w najbardziej wzniosłym sensie tego słowa ${ }^{28}$.

Wreszcie „Cyprynus" kończy list jawnym szantażem: „Jeżeli rozdział o Litwie nie otrzyma akceptacji Szanownego Pana, to sam Pan przyzna, że naturalnie i sprawiedliwie będzie, jeśli dalszą działalność przyjdzie mi skierować w inną stronę" 29.

Emerytowany cenzor nie rozumie, że właśnie taki efekt, wszystko na to wskazuje, chciał osiągnąć Barteniew, zmęczony zarówno kłótliwym charakterem, jak i temperamentem swojego kontrowersyjnego autora, a także naciskami wywieranymi przez wpływowych czytelników, z którymi wolałby nie spierać się o Osipa Antonowicza.

Dlatego tak rozpaczliwie brzmią słowa Przecławskiego, gdy broni swojej godności, będącej jednocześnie w jego oczach naturalnym prawem do odpowiedzi oponentom:

Prosząc mnie uprzednio o niezwracanie się do Pana ze skargami, zabiera mi Pan prawo, które przysługuje wszystkim bez wyjątku ludziom i we wszystkich możliwych okolicznościach. Pan, wielce szanowny Piotrze Iwanowiczu, zapomniał w tym przypadku o niezmienialnym aksjomacie prawnym: [...] „Skargę można pozostawić bez konsekwencji, ale zabraniać składania skarg..." ${ }^{30}$.

W tym momencie, jeśli weźmie się pod uwagę biografię autora tych zdań, raz walczącego z arbitralnością cenzury, innym razem usilnie pracującego na reputację twardego i surowego cenzora, przychodzi na myśl ironia losu i to, że ulubionym gatunkiem Historii jest tragikomedia.

\footnotetext{
27 W oryginale "Аитва десятых и двадцатых годов"

28 Tamże, a. 83 - 83 rew. [podkr. autora listu].

29 Tamże, a. 84.

30 О. A. Prżecławski, List do Р. I. Barteniewa z 4 stycznia 1873 r., РГААИ, zb. nr 46, nr inw. 1, jedn. arch. 565, a. 24 rew. -25.
} 
Wasilij Dawydow, wystąpiwszy kiedyś w roli pośrednika podczas starcia Przecławskiego z Barteniewem, prosi wydawcę "Rosyjskiego Archiwum”:

Chociażem otrzymał od niego [O. A. Przecławskiego - A. F.] bardzo szczegółowe na ten temat informacje, nie będę teraz wchodził $w$ analizę słuszności jego argumentów, ale pozwolę sobie zwrócić się do Pana z pokorną prośbą, aby, jeżeli nie ma innych wyjątkowych, nieznanych mi okoliczności, zakończyć tę sprawę w następujący sposób.

Jedynym jego pragnieniem jest to, żeby odebrać od Pana wysłaną przez niego pierwszą część artykułu Litwa w drugiej i trzeciej dekadzie XIX w. razem z anulowaniem jego obowiązku publikowania wyłącznie w „Ros[yjskim] Arch[iwum]" swoich wspomnień na tej podstawie, że umowa zawarta między wami odnośnie jego współpracy z powodu zaistniałych okoliczności rozwiązuje się sama przez się i przestaje obowiązywać. To daje prawo p. Prżecławskiemu do druku swoich dzieł w innych wydawnictwach. Co do obowiązku niedrukowania Kalejdoskopu w formie książkowej przed upływem roku od dnia druku w "Archiwum" ostatniego jego rozdziału, pozostawałoby to $\mathrm{w}$ mocy pomimo anulowania waszej umowy.

Oto, czcigodny Piotrze Iwanowiczu, tak wygląda nasza wspólna z p. Prżecławskim prośba. Wydaje mi się, że może być w pełni przez Pana przyjęta, jeśli nie ma innych przeszkód. O ile rozumiem, nie ma Pan już zamiaru drukować u siebie jego Wspomnień z powodu ich braku [z powodu braku ich kolejnych części - przyp. tłum.], i dlatego jaka mogłaby być z tego korzyść dla Pana? Dlaczego więc nie miałby Pan nie zwrócić jego rękopisu i anulować z nim umowy, która obowiązywała wcześniej, ale obecnie nie ma zastosowania. Ten słabowity stary człowiek, także chory, czeka na swoje rękopisy od Pana; ma zamiar drukować swoje opowiadania. Niech Pan nie staje mu na przeszkodzie i odeśle jego rękopis i umowę krewnemu, Włodzimierzowi Sawieljewiczowi Prżecławskiemu, na Bulwar Piotrowy do domu. Jeżeli moja szczera o to prośba może mieć jakiś wpływ na Pana decyzję, będę szczęśliwy, mogąc pomóc w pokojowym rozwiązaniu sprawy ${ }^{31}$.

Pragnienie emerytowanego cenzora zostało spełnione. Tak jak ustalono z Barteniewem, opublikowane w celu uzyskania honorariów oddzielne odbitki jego artykułów zostały połączone w jeden wolumen i ujrzały światło dzienne jako Kalejdoskop wspomnień Cyprynusa. Zeszyt 1. Drugiego zeszytu nie było. Przecławski nie odważył się także włączyć do pierwszego zeszytu Kalejdoskopu najbardziej kontrowersyjnego ze swoich pamiętnikarskich tekstów, tego, który wywołał istną eksplozję krytycznych ocen w prasie - fragmentu o Nikołaju N. Nowosilcowie.

31 W. D. Dawydow, List do Р. I. Barteniewa z 10 października 1873 r., РГААИ, zb. nr 46, nr inw. 1, jedn. arch. 565 (cz. 2), a. 235 - 236 rew. 
P. I. Barteniew pożegnał się z "Cyprynusem" nad wyraz nieelegancko. Wyliczając przewinienia nieszczęsnego pamiętnikarza, wydawca "Rosyjskiego Archiwum" kończy tekst pod tytułem $Z$ powodu wspomnień pana $C y$ prynusa następującym podsumowaniem:

Dopiero teraz, jak sądzimy, staje się oczywisty cel, z jakim drukowaliśmy te artykuły. Nie wspominaliśmy o nim wcześniej, żeby nie uprzedzać czytelników, tak by czytając artykuły bez pośredników, sami na sobie doświadczyli mocy wrażeń, sami zrozumieli, jak łatwo poddać się wpływowi trucizny, gdy jest podawana $\mathrm{w}$ tak eleganckiej, zamaskowanej formie, $\mathrm{z}$ takim uroczym aromatem szczerości. Dla większości rosyjskich czytelników to nowy, jeszcze nieznany alfabet, którego należy się uczyć, a uczyć się po to, by później bezbłędnie analizować niektóre skomplikowane dokumenty historii rosyjsko-polskiej. [...] Rosyjska natura zdecydowanie odeprze otwartego wroga, czy to fizycznego czy psychicznego; ale zachwieje się, zbytnio się zachwieje, gdy ten wróg przystąpi do niej z miodowymi usty, z wyrazami pokory wobec swego losu, ze słowami pojednania. Oto dlaczego do rosyjskiego człowieka dobrze pasują, jak widać, paradoksalne słowa: zbawcie mnie od przyjaciól, bo z wrogami sam sobie jakoś poradzę 32 .

Próba drukowania tekstu wspomnień za życia autora w innych wydawnictwach - głównie u M. I. Siemiewskiego w "Starożytności Rosyjskiej” również nie przyniosła Osipowi Antonowiczowi ani sławy, ani pieniędzy. Przy czym, jak się zdaje, nie spodziewał się on ani jednego, ani drugiego. Był już w takim wieku, kiedy, jak mówił jego przeciwnik, inny były znany cenzor, Paweł Kukolnik, ,jeżeli może powstać jakaś wątpliwość z tego powodu, że, w szczególności na początku artykułu, mówię o sobie jako o postaci jeszcze żyjącej, to pamiętajcie, że sądząc po moim wieku wkrótce i mnie przekażą do archiwum!!" 33 .

Archiwum Osipa Antonowicza Przecławskiego nie zachowało się.

tłum. Andrzej Zawadzki

32 П. И. Бартенев, По поводу воспоминаний г-на Ципринуса, RA 1873, nr 1, kol. 1056.

33 P. W. Kukolnik, List do P. I. Bartenewa z 15 września 1873 r., РГА ИИ, zb. nr 46, nr inw. 1, jedn. arch. 565 (cz. 2), a. 137. 


\title{
Cursed and Forgotten? \\ Scenes from the Life of Józef Emmanuel Przecławski. Part 2
}

\begin{abstract}
Summary
The article is devoted to the controversial, pro-Russian Polish editor of "Tygodnik Petersburski", Józef Emmanuel Przecławski. He was the alumnus of the Vilnius University and a contemporary of Adam Mickiewicz and the Philomaths, later to become loyal to the Russian Empire. The author of the article uses the Russian socio-political background to analyse the correspondence between Przecławski, the periodical's censor and the Tsar's advisors who, over the objections of chief editor, collaborated to transform the weekly into a bilingual Polish-Russian edition. The analysis is based on citations from the Russian archives sources.
\end{abstract}

Keywords: journalism, Tygodnik Petersburski, Józef Emanuel Przecławski, Russian Empire 